JEL: P25, Q13, Q14

Oleh Skydan, Olha Budnik, Lesya Sus

Polissia National University

Ukraine

\title{
THE ROLE OF AGROHOLDINGS IN THE CREATION OF COOPERATIVES BY RURAL COMMUNITIES
}

Purpose. The purpose of this study was a theoretical and methodological generalization of the agroholdings' social initiatives within their charitable activities with the interaction of cooperatives based on the institutional model.

Methodology / approach. This study was based on applying the general economic and special methods. The abstract-logical method was used for scientific discussion and scientific views about the role of agroholdings and their impact on the rural population. The method of critical analysis was applied to outline the social aspects of agroholdings' activities. The system approach allowed contouring the main problems that arise in the process of agroholding growing. The study of the state of agricultural cooperatives' financing by agroholdings was also conducted. On the basis of the monographic method the motives and directions of the management of separate agroholdings within their social responsibility limits were defined. With the generalization method, the basic forms and resources of agroholdings' social responsibility were determined. Thanks to the correlation-regression analysis, it was established the relationship between the social responsibility indicator of agroholdings and their efficiency by EBITDA, as well as their social responsibility and market capitalization degree.

Results. The study examined the main scientific approaches to the role of agroholdings, which allowed outlining their ambiguity and contradictions. The systematization of the presented materials allowed developing arguments in favor of the agroholdings' functioning and identifying counterarguments of their activities as well as emphasizing the need of the basic methodological provisions for further harmonious development of agroholding structures and cooperatives. The results of the presented empirical analysis showed a low level of agroholdings' social responsibility, which affects the development of the rural areas and significantly increases social tensions. On the basis of the conducted research and data processing the mechanism of agroholdings' and cooperatives' interaction on the basis of social responsibility is offered. It was proved that the basis of the presented interaction must be financial and economic, social, marketing and environmental motives.

Originality / scientific novelty. It was improved the theoretical and methodological approach to the formation of institutional model of the agroholdings' and cooperatives' interaction on the principles of social responsibility, which provides financial and economic, social, marketing, environmental problems solutions by agroholdings and promotes the rural community's development in the near future.

Practical value / implications. The results of the study are of great practical importance and can be useful for various ownership forms of agricultural producers as well as for agricultural holding organizations which are interested in harmonizing the rural economy development.

Key words: agrarian sector, agroholdings, cooperatives by rural communities, social responsibility, rural society. 


\section{Agricultural and Resource Economics: International Scientific E-Journal}

http://are-journal.com

Introduction and review of literature. The private business entities, a significant position among which is held by the small enterprises, are the catalysts of the local and national economic development (Mura and Kljucnikov, 2018). Today, small and medium enterprises create the main part of gross domestic product in countries with developed market economies and in Ukraine too. Analysis of the domestic business structure shows that the most part of production belongs to small enterprises $(94.3 \%$ ) (Sliusar, 2019). At the same time, their functioning is determined by globalization and a significant increase in competition, and, consequently, requires the implementation of the latest agricultural techniques, methods and mechanisms, the energy and energy-saving technologies use. Under such conditions, it is extremely difficult for small enterprises to run their own business successfully and to be competitive. After all, high-performance innovations and technologies are too expensive for small agribusiness entities that carry out economic activities in the absence of financial, material, technical resources and the lack of opportunities to attract them.

Another problem that significantly hinders the Ukrainian agribusiness development is the lack of sale opportunity for manufactured products due to the absence of appropriate infrastructure. Therefore, producers are forced to sell manufactured products in natural markets, but, as V. Boiko et al. noted when wholesale markets and regional agrarian centers are created, buyers and sellers will be able not only to sell or buy products, but also receive a wide scope of services: storing, preparing goods for sale, transporting, making calculations, getting loans, obtaining information from consulting services etc. (Boiko et al., 2019). The imperfection of the mechanism of Ukrainian land relations regulation is manifested in the conflict of interests between rural households, local communities, authorities, farms, small, medium enterprises and agricultural vertically integrated holding companies (Kononenko, 2019). The solution of the identified problems depends on many factors: well-considered state policy of rural development, implementation of government programs by local authorities, the desire and perseverance of rural population on the way towards improving their own living conditions (Dema et al., 2019).

Agriculture is an industry that is entering the crisis more slowly than others, while other industries are experiencing a downturn (Onegina and Vitkovskyi, 2020). However, its operation is characterized by the dynamic processes, increased competition and the need to adapt to the European economic practices. This can only be achieved through cooperation and joint efforts. The world experience has confirmed the undeniable importance of the cooperative idea, the main purpose of which is to unite peasants and to optimize the conditions for their business operations. Agricultural cooperatives are the most common and effective form of such integration, the share of which in the EU agricultural market is $40-50 \%$ and up to $70 \%$ in the individual sectors. The annual turnover of the 10 largest farmer cooperatives in the EU is over 93 billion USD, which is almost equal to the annual Ukraine GDP (Sakovska, 2020). In addition, the farmers who cooperate and become 


\section{Agricultural and Resource Economics: International Scientific E-Journal}

http://are-journal.com

members of public organizations dominate the market, sell products more efficiently, buy means of production cheaper than buying them separately (Ramanauskas et al., 2017).

Ukrainian agribusiness differs from the world one because of the need to create not only traditional cooperatives for farmers or other enterprises, but also cooperatives by rural communities. According to L. Ivanova, the formal cooperative relations are based on commodity-money relations, which provides for maximum profit and relations within the rural community - mainly on the moral and ethical society norms (Ivanova, 2020). In this case, we see the essence of cooperative by the rural community in the producer's initiative association which can bring them to the fundamentally new management level and to improve their economic situation by the private needs concentrating while using a flexible, optimized pricing system; with the technical re-equipment possibility, farms modernization and production process improvement; expansion of the activity spheres; investment resources attracting; strategic relationships with counterparties establishing and the effective reduction of the economic risks.

This is impossible to achieve in the modern economic space with separate management. Contrary to the convincing prospects and advantages of cooperation, it has not yet found its proper distribution in the domestic agricultural sector of the economy. As V. Zinovchuk emphasizes, in recent decades, cooperative development strategies, closely aligned with the sustainable development goals of the agricultural sector and rural areas, have become widespread in many countries, mostly developed ones. For Ukraine, with rare exceptions, it is still terra incognita, although the need to initiate such trends in the evolution of the cooperative movement is obvious and urgent (Zinovchuk, 2020). We share this vision on the relevance of the cooperative idea and its inseparability for agriculture. Besides, the introduction of the cooperative movement effective mechanism in agribusiness will have a complementary social and economic effect (Budnik, 2019). We support V.Zinovchuk's vision about the cooperative idea and its inseparability for agriculture. We should remark that, despite a number of reasons and public resistance caused by ignorance of the cooperation benefits, the sprouts of the cooperative movement still exist. In some cases, the initiators of this process are agroholdings. In this regard, the question arises about the reasons and motivating of such agroholdings' activity.

The study of the theoretical and methodological aspects of agroholdings' activity has received considerable attention from well-known researchers. The agricultural holdings occurrence is associated with the range of increasing raw materials as well as their competitiveness enhance by a closed business cycle, logistics, the coordinated management of the entire production chain creating, reducing the financial business risks and a separate brand formation (Cherevko, 2012). As Y. Prokopenko points out, the development of holding structures opens new opportunities for the population and for local government, creates preconditions for the country social sphere decline suspension, reduces the outflow of rural residents to cities, promotes agricultural production (Prokopenko, 2019). M. Lazareva 
emphasizes that the significant advantage of the integration processes is mainly transaction costs saving (Lazareva, 2018). Objectively, their management level is much higher than in other forms. Moreover, as noted T. Zinchuk et al. the crop capacity level (especially for cereals and legumes) in the enterprises-participants of vertically integrated business structures is much higher compared to the other producers (Zinchuk et al., 2019).

It should be objectively acknowledged that the level of the agroholdings' management is much higher compared to other entrepreneurial forms. Along with this, O. Moroz et al. suggested that the land concentration leads to the productivity labor sharp increase and it results the reduction in the employer's number, so the social impact of agroholdings' activities can be assessed negatively. They concluded that agrarian corporations, as the only economically recognized path of development, lead to the same trap in which soviet-era agriculture found itself on the eve of market reforms. And these problems are complex (Moroz et al., 2014). R. Levek emphasizes that in Ukraine, in agricultural holdings with an area of 5-30 thousand hectares growing cereals, $80 \%$ of value added is returned to the owners of capital, land tenants, while employers receive less than $10 \%$ and about $8 \%$ are given to landowners (Levek, 2020).

L. Zaburanna and Yu. Yarmolenko said that the result of the agroholdings' activities has become a threatening level of indicators related to the environment: the application of mineral fertilizers since 2000 year has increased 6 times, organic almost 3 times; the level of arable land use increased from $79.7 \%$ in 2000 year to $85.4 \%$; the share of the most profitable maize, sunflower and rapeseed, which is extremely depleting arable land, increased from $16.6 \%$ in 2000 to $41 \%$ in 2016 (Zaburanna and Yarmolenko, 2017). M. Pidgrebelna also notes that it is useless to expect the environmental effects of the agroholdings' functioning. It can be explained by the facts that these economic structures are maximum profit orientation (Pidgrebelna, 2013). This view is supported also by T. Ozhelevska, who emphasizes that the further agriculture development through the agroholdings' expansion and prosperity will lead to the complete destruction of rural areas (Ozhelevska, 2011). Yu. Khalep and A. Moskalenko indicated that the environmental aspects of production efficiency and the consequences of increasing anthropogenic pressure on the environment are often underestimated and the degree of their consideration depends mainly on the level of environmental awareness of a particular entity (Khalep and Moskalenko, 2020). We agree with the authors' scientific position that the ecological state of production is threatening the rural areas. However, it should also be noted that this trend is typical for almost all modern agribusiness forms (farms, private enterprises, etc.) and not only for agricultural holdings.

Summarizing the leading researchers' views and opinions, we can say that the emergence of agricultural holdings is a consequence of the post-reform period of domestic development. This form of economic activity has significant advantages, such as the ability to produce large goods consignments, obtaining a "scale effect", to integrate production and processing, to optimize the sales and trade, to avoid the 
intermediaries, the high-tech operations and innovative technologies use. In addition, practice of agroholdings leads to a significant slowdown in the development of small agricultural enterprises, due to the inability to compete because of lack of the main resources. However, small agricultural enterprises contribute to the rural population self-sufficiency, its survival in today's extremely difficult economic conditions, that deepened by the global pandemic.

The purpose of the article was a theoretical and methodological generalization of the agroholdings' social initiatives within their charitable activities with the cooperatives interaction on the basis of institutional model.

Results and discussion. The emergence of agroholdings is a natural process and a consequence of transformational changes in the agricultural sector. However, regulatory irregularities, the lack of a proper institutional environment and the instability of the economic development in domestic agricultural sector, extended by inflation and the crisis, has provoked a number of challenges for the functioning of small and medium-sized agricultural enterprises. Despite attempts to ensure of management organizational and legal forms parity, large business units are dominant. They are the undisputed leaders in the production and sale. Such imbalance gives them the opportunity to penetrate into new areas; to be financially stable and have a strong material and technical base; to be innovative and investment attractive; to have stable market positions based on constant market conditions monitoring; vary prices due to the possibility of reducing the production cost; to establish a system of goods supply and sale; be effective in communicating with consumers.

Along with that, the comprehensive expansion of agroholdings and growth led to the hypercapitalization and to the occurrence of agromonopolies. Therefore, according to T. Zinchuk and Ye. Levkivskyi, the practice of companies, including agricultural holdings, require a business philosophy change in the direction of strengthening in their social mission and responsibility to future generations on maintaining prosperity and a decent quality of life (Zinchuk and Levkivskyi, 2019). The current socio-economic situation in Ukrainian villages is far from the European standard of living. O. Borodina et al. pointed out that, the agroholdings participate in the construction of country social infrastructure objects (The community..., 2015). At the same time, it should be noted that social responsibility should not be limited only by charity in the rural infrastructure development. Such position as social business responsibility is too little compensation for rural communities.

We agree with the definition of an agroholding "as an association of different organizational and legal form of agricultural enterprises aimed at maximizing the economic effect" (Dankevych, 2011). We believe that their interaction with cooperatives in rural communities will provide an opportunity to receive complementary economic benefits as well as social benefits, social progress and can significantly increase their prestige in rural society.

The issue of the introduction of social responsibility by agricultural enterprises are considered by L. Levkivska and L. Levkovych (2017); A. Mints et al. (2020) and many others. O. Pasko et al. noted that they were the first scientists, who analyzed 
deep the process of the formation of Ukrainian agricultural holdings (Pasko et al., 2021). Moreover, I. Irtyshcheva and T. Stroyko underscore that it is socially oriented activities bring companies tangible benefits, so they operate much more successfully and efficiently than companies that do not have such programs, by strengthening their reputation and image, improving the efficiency of doing business and investment attractiveness of the company (Irtyshcheva and Stroyko, 2013). T. Galetska et al. also notes that features of the current socio-economic situation require strengthening of their socially responsible behavior, introduction and observance of new interaction forms between business and society on the principles of systematic and long term (Galetska et al., 2020). In support to these scientific attitudes, it should be noted that the implementation of social responsibility by agricultural holdings becomes part of their business strategy and advertising card to build the commitment of rural communities and one of the most promising areas of their development is the social adaptability. Therefore, reconciling the interests of holdings and rural residents by creating cooperatives for them in rural communities can become an integral part of balanced economic development of Ukraine, as the main purpose of such cooperation is compliance of social functions. Ultimately, this may determine the undeniable importance and uniqueness of this cooperation, which will help agricultural holdings solve the farmer's problems, including social.

Agroholdings with the foreign investment, which transfer modern world practices, principles and standards of cooperation to Ukrainian business are active in the social responsibility policy. This is confirmed by the empirical experience of the "Continental Farmers Group", whose charitable foundation gives financial support for cooperatives' establishment by the rural communities. In particular, since 2015 (the agroholding was called "Mriya"), its fund has invested more than $1.5 \mathrm{mln}$ UAH to the cooperative movement development. Their main funds were directed to the necessary equipment purchase. In addition, part of the agroholdings' equipment was transferred to the cooperative members. During 2018, the agroholding implemented a number of social projects in six regions of the Western Ukraine (this is $27.4 \mathrm{mln}$ $\mathrm{UAH})$. Besides, thirty cooperatives were allocated in the Khmelnytsky region with its support (SMIDA, 2020).

The agricultural holdings with foreign investments, which attract funds on public platforms - stock exchanges, are more actively introducing modern world practices, principles and standards of cooperation with rural society into domestic business and form a policy of social responsibility. During 2015-2019, 14 Ukrainian agricultural holdings placed their shares on the international stock exchanges (Table 1).

The placement of shares requires such companies to have an appropriate level of transparency and accountability. However, some companies in the agricultural sector do not report about social responsibility and their sustainable development (Table 2).

Among the 14 agroholding companies whose securities are listed on the world stock exchanges only 6 companies provide information about their social responsibility directions (that is $43 \%$ and only three companies the non-financial 
reports form and GRI Standards are used (that is $21 \%$ ). This information makes it possible to single out 3 groups of agricultural holdings that cover social responsibility projects: companies that do not provide any information; companies have only websites information about the social responsibility; companies that disclose information, including using the Global Reporting Initiative (GRI) approaches.

Table 1

The dynamics of the capitalization of agroholdings, whose securities are listed on the world stock exchanges, mln USD

\begin{tabular}{|l|c|c|c|c|c|}
\hline \multirow{2}{*}{ The agricultural holdings } & \multicolumn{5}{c|}{ Years } \\
\cline { 2 - 6 } & 2015 & 2016 & 2017 & 2018 & 2019 \\
\hline Ukrproduct Group & 3.4 & 1.8 & 1.6 & 2.9 & 2.1 \\
\hline Milkiland & 18.9 & 14.5 & 18.1 & 5.8 & 2.5 \\
\hline KSG Agro & 3.5 & 5 & 103 & 3.5 & 3.1 \\
\hline Cereal Ukraine & 5.7 & 5.8 & 5.1 & 4.7 & 4.5 \\
\hline Agroliga & 3.6 & 5.5 & 7.5 & 5.7 & 6.2 \\
\hline AgroGeneration and Harmelia & 48.7 & 37 & 37.8 & 36.8 & 13.6 \\
\hline UkrLandFarming inc. Avangardco & 168 & 57.5 & 46 & 21.1 & 17.9 \\
\hline Trigonagri (Agromino) & 15.2 & 5.1 & 2.5 & 33 & 30.6 \\
\hline Agroton & 10.5 & 6.7 & 32.8 & 90.7 & 89.1 \\
\hline Industrial dairy company & 43.1 & 58.7 & 78.8 & 96.7 & 119.1 \\
\hline Astarta-Kyiv & 143.2 & 246.2 & 427.6 & 203.1 & 156.5 \\
\hline Ovostar Union & 109.5 & 152.8 & 143.4 & 169.2 & 177.2 \\
\hline Myronivs'kyy khliboprodukt & 1042.6 & 914 & 1030.3 & 1273.3 & 1093.7 \\
\hline Kernel Group & 825.8 & 1127.1 & 1462.4 & 1017.4 & 1109.1 \\
\hline Total & 2441.7 & 2637.7 & 3396.9 & 2963.9 & 2825.2 \\
\hline
\end{tabular}

Source: based on SMIDA Database (2020).

In order to better understand the situation, this study conducted a correlationregression analysis to establish the degree of the closeness between social responsibility, market capitalization and the EBITDA efficiency.

The study of the factors that influence on the social consciousness of agroholdings was conducted in several stages:

1) collection of the information for systematization of the factors that influence on the social agribusiness responsibility formation. To build the model, separate indicators of financial and economic activity of agricultural holdings were selected, such as: market capitalization indicator and EBITDA indicator. The market capitalization of agroholdings is calculated as the total value of all its shares by multiplying the number of shares by the current market price. When constructing the model, the EBITDA indicator was used, which is equal to the company's profit before deducting expenses on bank interest, taxes and depreciation deductions. The indicator is calculated on the basis of the company's financial statements and is used to assess how profitable the main activity is;

2) the calculation of the importance of factors influencing on the social responsibility of agroholding is based on the significance of used factors with the correlation-regression method, which allows building a descriptive model and to interpret the real situation or development trends. 
The implementation of the social initiatives of Ukrainian agricultural holdings in the sustainable development framework

\begin{tabular}{|c|c|c|c|}
\hline Name & $\begin{array}{c}\text { Cost, } \\
\text { mln } \\
\text { UAH }\end{array}$ & Summary & Directions of social projects \\
\hline $\begin{array}{l}\text { Ukrproduct } \\
\text { Group }\end{array}$ & - & \multirow{3}{*}{\multicolumn{2}{|c|}{$\begin{array}{l}\text { Do not report or publish } \\
\text { any information } \\
\text { on social responsibility }\end{array}$}} \\
\hline Agroton & - & & \\
\hline Cereal Ukraine & - & & \\
\hline $\begin{array}{l}\text { AgroGeneration } \\
\text { and Harmelia }\end{array}$ & - & \multirow{5}{*}{$\begin{array}{l}\text { The companies' } \\
\text { website provide } \\
\text { only brief } \\
\text { information } \\
\text { about their } \\
\text { social } \\
\text { responsibility } \\
\text { projects }\end{array}$} & $\begin{array}{l}\text { support for Children's houses, hospitals, schools, } \\
\text { houses for veterans and war veterans }\end{array}$ \\
\hline Agroliga & - & & $\begin{array}{l}\text { the educational projects implementation in } \\
\text { cooperation between business and educational } \\
\text { institutions }\end{array}$ \\
\hline Milkiland & - & & $\begin{array}{l}\text { implementation of the social project "School of } \\
\text { Children's Swimming", support to municipalities, } \\
\text { public organizations that help the socially } \\
\text { disadvantaged people }\end{array}$ \\
\hline Ovostar Union & - & & $\begin{array}{l}\text { the company trying to achieve balance of the quality } \\
\text { of environmental procedures, high social standards } \\
\text { for employees and local communities }\end{array}$ \\
\hline $\begin{array}{l}\text { Trigonagri } \\
\text { (Agromino) }\end{array}$ & - & & $\begin{array}{l}\text { assistance to schools, preschools, in the sports } \\
\text { grounds construction, children support, students and } \\
\text { veterans' organizations support }\end{array}$ \\
\hline KSG Agro & 1.5 & \multirow{3}{*}{\begin{tabular}{|c} 
Do not report \\
about sustainable \\
development \\
practices, but \\
there is an online \\
information about \\
social \\
responsibility
\end{tabular}} & costs for COVID protection equipment \\
\hline $\begin{array}{l}\text { UkrLandFarming } \\
\text { inc. Avangardco }\end{array}$ & 0.5 & & $\begin{array}{l}\text { support for hospitals, schools, preschools, low- } \\
\text { income groups }\end{array}$ \\
\hline IMK & 18.0 & & $\begin{array}{l}\text { assistance to schools, kindergartens, medical and } \\
\text { obstetric points, repairs of roads, water mains, } \\
\text { lighting of settlements, financing of football teams, } \\
\text { sponsorship of regional cultural events }\end{array}$ \\
\hline Astarta-Kyiv & 33.4 & \multirow{3}{*}{$\begin{array}{c}\text { Disclose } \\
\text { information on } \\
\text { sustainable } \\
\text { development } \\
\text { using Global } \\
\text { Reporting } \\
\text { Initiative } \\
\text { approaches }\end{array}$} & $\begin{array}{l}\text { investments in infrastructure development, } \\
\text { landscaping, education, culture, sports, medicine, } \\
\text { environmental protection }\end{array}$ \\
\hline MHP & 78.0 & & $\begin{array}{l}\text { interaction with communities, quality and safety, } \\
\text { counteraction to COVID, educational program } \\
\text { "School - the heart of the community" }\end{array}$ \\
\hline Kernel Group & 39.6 & & $\begin{array}{l}\text { support of local communities in social areas } \\
\text { (education, medicine, sports), the implementation of } \\
\text { infrastructure improvement projects, Charitable } \\
\text { Foundation "Together with Kernel" }\end{array}$ \\
\hline
\end{tabular}

Source: own processing.

We consider the representativeness of the sample to be high, as it includes $100 \%$ of agroholdings in Ukraine, which attract investment by selling their shares on the world stock exchanges and provide financial information on social responsibility in the framework of sustainable development. After all, the fact of these agroholding 
structures publicity stimulate them to introduce their business social responsibility. The sample included 6 agricultural holdings: Kernel, Astarta-Kyiv, IMC, Myronivsky Hliboproduct (MHP), Avangardco, KSG Agro. Analysis of the impact of EBITDA efficiency on the size of agricultural holdings social responsibility is presented in Fig. 1.

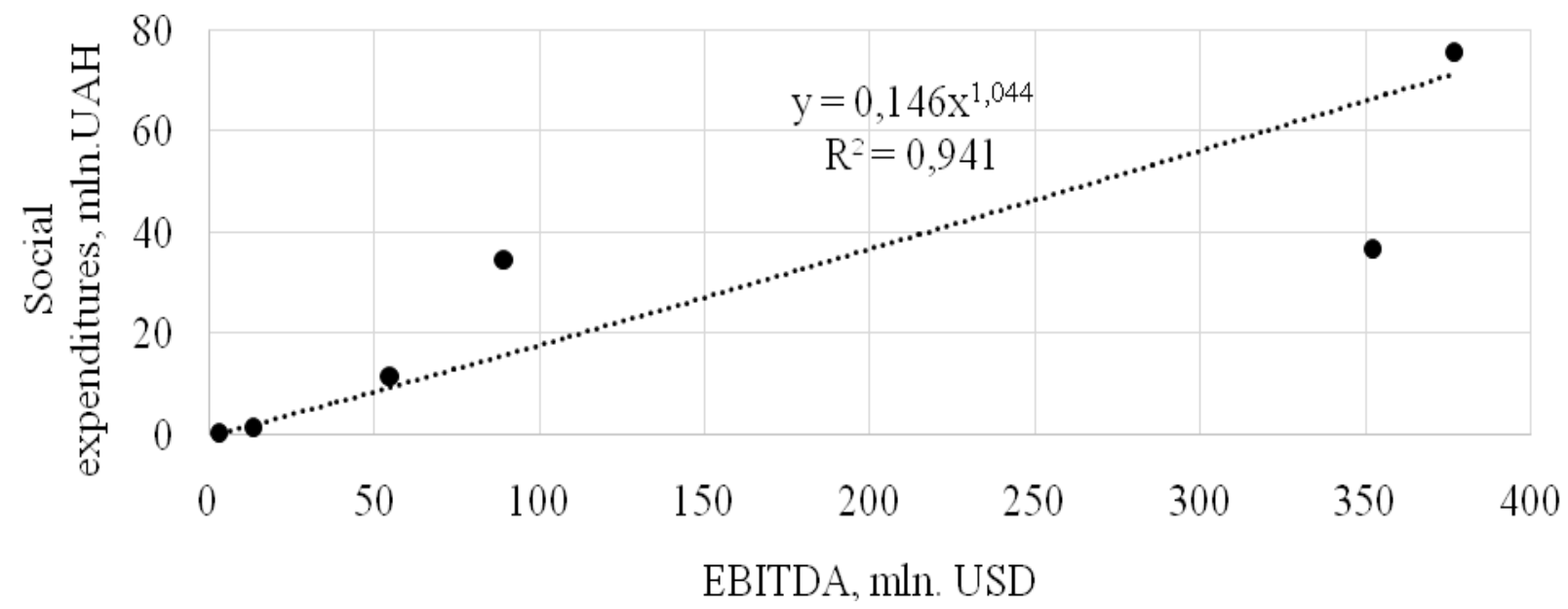

Fig. 1. The impact of the production efficiency on the social responsibility volume of Ukrainian agroholdings

Source: based on SMIDA Database (2020).

The correlation analysis showed that in the period 2015-2019 the social responsibility volume of agricultural holdings largely depended on the EBITDA efficiency and has a high degree of closeness $\left(\mathrm{R}^{2}=0.9417\right)$. It is established that there is also a rather close relationship between social responsibility and market capitalization $\mathrm{R}^{2}=0.7896$ (the regression equation, in this case, shows the inverse relationship between the resultant feature and the chosen factor). The degree of connection between the social responsibility and the market capitalization is presented in Fig. 2.

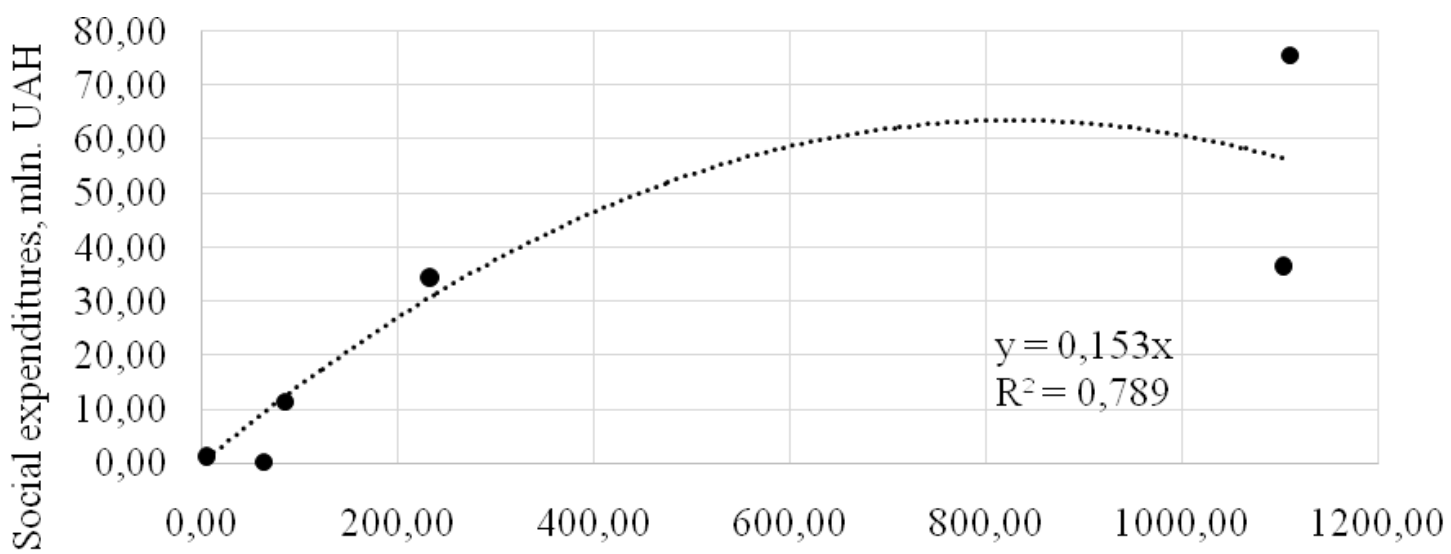

Market capitalization, $\mathrm{mln}$. USD

Fig. 2. The impact of the market capitalization on the social responsibility volume of Ukrainian agroholdings

Source: based on SMIDA Database (2020). 
The highlighted models are used to predict the trends of influencing and establishing the level of the productive trait dependence (social responsibility volume) of the factor (agricultural holdings efficiency and capitalization level) and, consequently, the support of rural society. It can be assumed that the purpose of such an initiative is to reduce social tensions and dissatisfaction of the rural population. The result of the rural community's cooperatives establishment is a real opportunity for new jobs creation, small business intensification, infrastructure building, for the large-scale industrial production facilities without environmental pollution appropriation and so on. Such an approach will eliminate the negative consequences of overconcentration.

Some examples of the cooperatives' creation by rural communities with the agricultural holdings participation through the financial and technical assistance have already proved their viability. The motivation for cooperation of agricultural holdings and cooperatives relations is presented in Fig. 3.

According to the A.Carroll's classical position the corporate social responsibility is multilevel, where the first level is legal responsibility and the last one is the philanthropic (voluntary) (Carol, 1991).

In the course of this study, the analysis of the corporate social responsibility policy of agroholdings made it possible to identify four areas of interaction with cooperatives:

1) the financial and economic, which consists of the product and assortment policy extension; the intermediary link elimination; the effective marketing policy establishment, that help to deliver products to the consumer. In addition, such cooperation allows constructing the certification and standardization centers thanks to the support of agroholdings, which is especially relevant for personal rural communities or farms, which, are forced to sell products at too low prices or in the natural markets now;

2) the social, that is the rural society unemployment problems solving through involving them to the business proceedings and, as a consequence, reducing the rural population social dissatisfaction because of the excessive spread of agroholdings;

3) the marketing, which implies the consumers' needs and requests studying priority with comprehensive marketing research. It means the development of strong recognizable powerful brands, that will be competitive both in the domestic and foreign markets;

4) the ecological, in the case of their own private lands activities processing, rural population use land resources economically, that help to reduce the environmental anthropogenic load. In addition, private owners pay considerable attention to the land fertility restoration and conservation due to resource-saving technologies use. Ultimately, such activities lead to an environmental awareness of conducting business operations and to the considerable rising offered production competitiveness. 
Agricultural and Resource Economics: International Scientific E-Journal http://are-journal.com

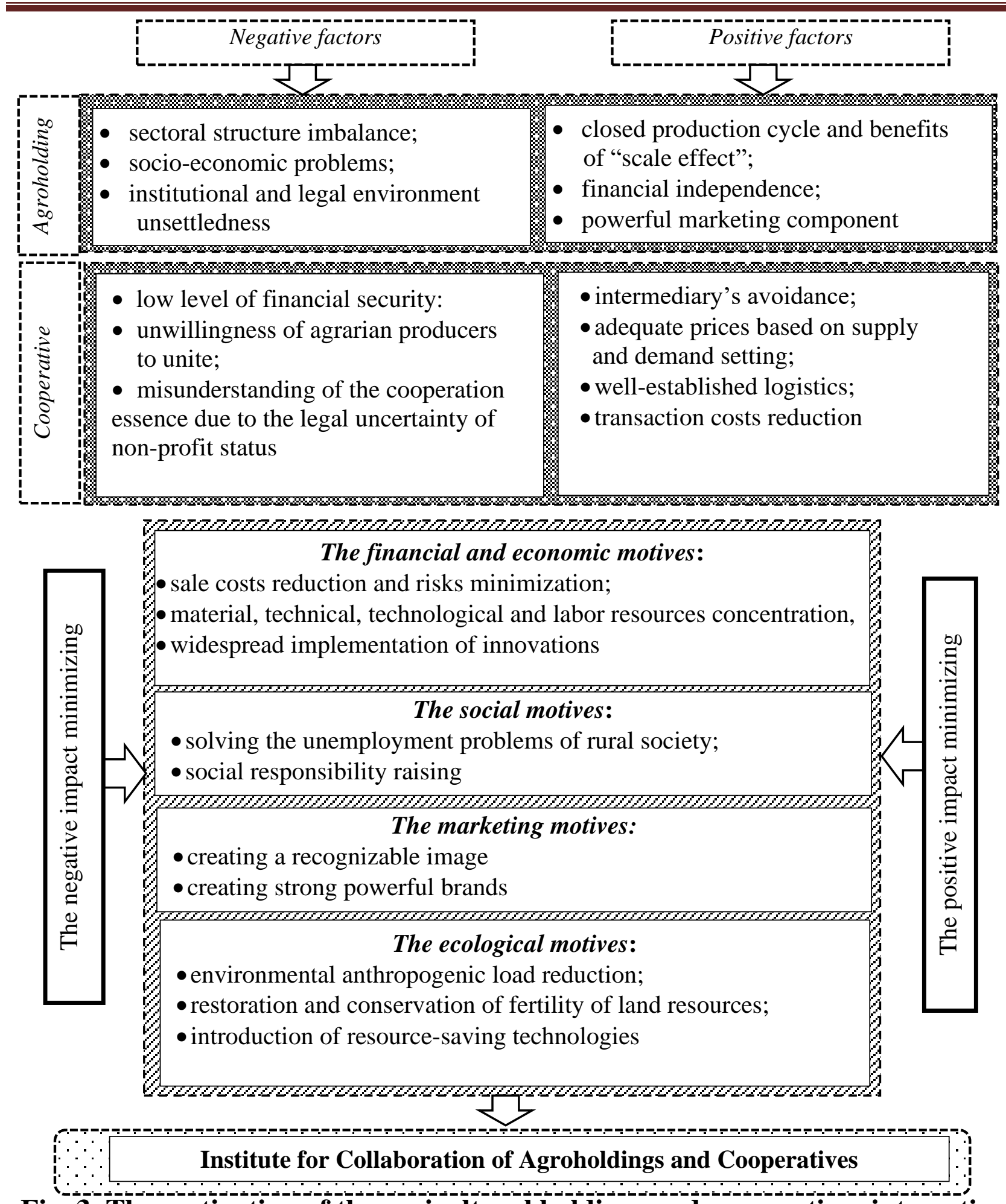

Fig. 3. The motivation of the agricultural holdings and cooperatives interaction

Source: own processing.

Up to now, the activity of agricultural holdings was inert and directed not to the economic or social growth, but only to the agribusiness owners' ambitions and needs. Therefore, the establishing cooperation of agricultural holdings will mean smoothing the negative consequences and minimizing social tensions to the rural areas through business processes with sustainable development combination. In addition, the development of the agricultural holdings and cooperatives interaction model and its 


\section{Agricultural and Resource Economics: International Scientific E-Journal http://are-journal.com}

implementation to practice can serve as the beginning of large-scale structural changes in agribusiness aimed at stimulating institutional changes (Fig. 4).

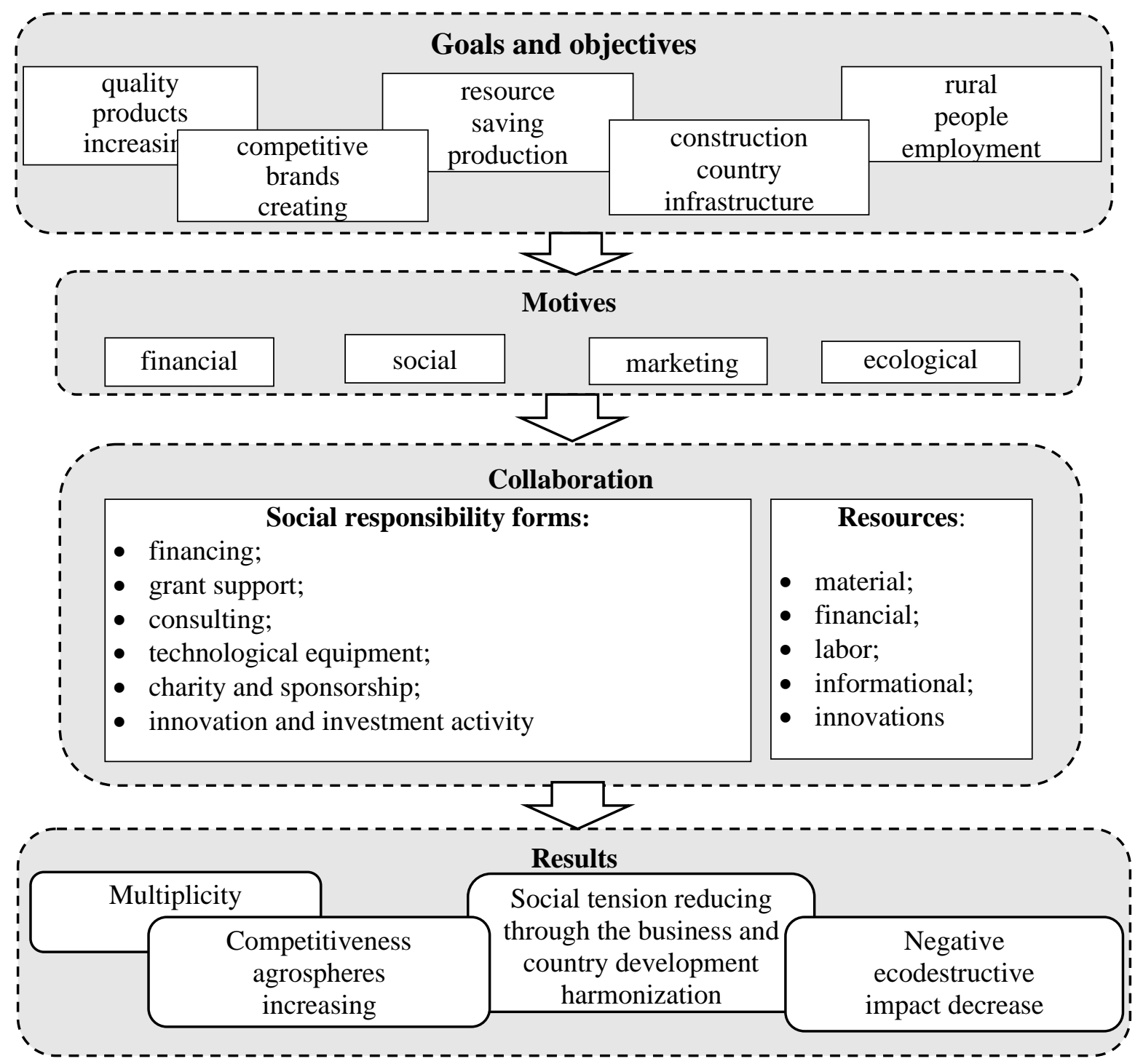

Fig. 4. The institutional model of the agricultural holdings and cooperatives

Source: own processing. coexistence on the basis of social responsibility

The advantages of the proposed cooperation will be agricultural holdings assistance in providing for cooperatives the following: (a) logistical resources; (b) financial resources (assistance in the cooperatives setting up as well as charitable and sponsorship funding); (c) labor and information resources (that is: advisory and consulting services on a free basis); (d) innovative resources (through the agroholding grants distribution).

The developed model represents the association of groups, each of which pursues its own goals. According to the institutional model, the functioning of the organization is determined not only by the rationality of the structure, socioeconomic demands of its members as individuals, but also by taking into account the demands of social groups operating both inside and outside the organization. We 
believe that the agricultural holdings practice in providing the financial support for the establishment of cooperatives by rural communities aims to resolve conflicts that arise in rural areas and emphasizes their desire to support the population in creating and running individual businesses. For their part, agroholdings will receive raw materials for the finished products production in the required quantity (for example: milk and berries from cooperatives for the yogurts or any other dairy products production). The mutual benefit of such relationship organization will be obtaining a multiplier effect for both agricultural holdings and cooperation participants. The result will be in increasing competitiveness of small and medium-sized enterprises and the reduction of social tension due to harmonization of the interests of rural residents and business as well as reduction of the negative eco-destructive impact on land resources.

Conclusions. The received results of the research, which possess the significant empirical importance, are: the formation of the institutional model of the agricultural holdings and cooperatives collaboration on the social responsibility basis, aimed at reducing the negative aspects of the holding structures functioning in the rural areas. Such interaction will be carried out with the resource involvement of agroholdings, including financial, technical, labor, information and innovation resources. According to the authors' opinion, the main stimulus for such relationships for agricultural holdings will be the need to reduce social tensions in rural areas, and for the rural population - the intention to bring their own business out of crisis as well as the desire to implement entrepreneurial ambitions, ideas and projects. In the proposed institutional model, the agroholding is an organizational and economic functional coordination mechanism for global changes.

It is not necessary to draw premature conclusions at the moment, but the approval of this initiative by the rural residents can be considered as one of the steps forward. It is very important to increase the level of awareness of farmers about cooperative benefits and agroholding support, which will contribute to the effectiveness of this approach. We believe that the introduction and dissemination of the cooperative idea in rural areas can objectively become an aggregator of efficiency of economic operations and will allow achieving parity of market interaction in the chain agroholding - cooperative, and the indicator of such cooperation will be the social component. Calculations in this direction have shown that in most agricultural holdings there is an inversely proportional relationship between their capitalization and their social responsibility level, instead, the establishment of such cooperation will harmonize the relationship between large businesses and rural society.

The further research prospects are to develop efficient mechanism that will allow the business entities, individual agricultural producers and government agencies collaboration setting up. It is also important to pay attention to the appropriate legal framework developing that will help to create a proper business and entrepreneurial climate.

\section{References}

1. Mura, L. and Kljucnikov, A. (2018), Small businesses in rural tourism and 
agrotourism: study from Slovakia. Economics and Sociology, vol. 11, no. 3, pp. 286300. https://doi.org/10.14254/2071-789X.2018/11-3/17.

2. Sliusar, S. (2019), Business in modern conditions of management. Baltic Journal of Economic Studies, vol. 5, no. 2, pp. 206-213. https://doi.org/10.30525/2256-0742/2019-5-2-206-213.

3. Boiko, V., Misiuk, M., Kwilinski, A. and Boiko, L. (2019), Competitive advantages of wholesale markets of agricultural products as a type of entrepreneurial activity: the experience of Ukraine and Poland. Economic Annals-XXI, vol. 175, is. 1-2, pp. 68-72. https://doi.org/10.21003/ea.V175-12.

4. Kononenko, O. (2019), Transformation of land relations regulation mechanism throughout the rural sustainable development context. Agricultural and Resource Economics, vol. 5, no. 1, pp.9-36. https://doi.org/10.22004/ag.econ.287139.

5. Dema, D., Abramova, I. and Nedilska, L. (2019), Financial and economic conditions of rural development in Ukraine. Eastern Journal of European Studies, vol. 10, no. 1, pp. 199-220.

6. Onegina, V. and Vitkovskyi, Yu. (2020), Investments and land reform in agriculture of Ukraine. Agricultural and Resource Economics, vol. 6, no. 4, pp. 187210. https://doi.org/10.51599/are.2020.06.04.10.

7. Sakovska, O. (2020), Agricultural cooperation: experience of foreign countries for Ukraine. Baltic Journal of Economic Studies, vol. 6, no. 1, pp. 118-124. https://doi.org/10.30525/2256-0742/2020-6-1-118-124.

8. Ramanauskas, J., Žukovskis, J. and Zinovchuk, V. (2017), Agricooperatives and producer's organisations: case of EU countries and lessons for Ukraine. Management Theory and Studies for Rural Business and Infrastructure Development, vol. 39, no. 3, pp. 333-346. https://doi.org/10.15544/mts.2017.24.

9. Ivanova, L. (2020), Interaction problems of agricultural cooperatives and bodies of the united territorial community in the conditions of decentralization of power. Agrosvit, vol. 21, pp. 35-40.

10. Zinovchuk, V. (2020), The global environmental trends in the cooperative agromarketing. Orhanichne vyrobnytstvo ta prodovolcha bezpeka [Organic production and food security], Mizhnarodna naukovo-praktychna konferentsia [International scientific-practical conference], Polissya National University, Zhytomyr, Ukraine, May 21, 2020, pp. 184-190.

11. Budnik, O. (2019), Agricultural cooperation in the market transformation conditions: the current state and the development prospects. Vcheni zapysky TNU imeni V. I. Vernadskoho. Seriia Ekonomika ta Upravlinnia, vol.30(69), no. 6, pp. 48-53. https://doi.org/10.32838/2523-4803/69-6-9.

12. Cherevko, G. (2012), Agroholdings as new organizational forms of largescale management in agribusiness of Ukraine. Agrarian economy, vol. 5, no. 1-2, pp. 36-42.

13. Prokopenko, Y. (2019), The transaction costs in the logistics system of APK. Vcheni zapysky TNU imeni V. I. Vernadskoho. Seriia Ekonomika ta upravlinnia, 


\section{Agricultural and Resource Economics: International Scientific E-Journal}

http://are-journal.com

vol. 30(69), no. 6, pp. 70-76. https://doi.org/10.32838/2523-4803/69-6-13.

14. Lazareva, M. (2018), Transaction costs and synergy effects in modern corporations. Economic Annals-XXI, vol. 171, no. 5-6, pp. 23-28. https://doi.org/10.21003/ea.V171-04.

15. Zinchuk, T., Nykoliuk, O. and Pyvovar, P. (2019), Features of functioning of vertically integrated business structures of holding type in the agrarian sector. Ekonomika APK, no. 9. pp. 19-30. https://doi.org/10.32317/2221-1055.201909019.

16. Moroz, O., Semtsov, V., Marchenko, S. and Fedorishina, O. (2014), Evaluation of organizational changes in agriculture Ukraine by concentration of land resources. Scientific messenger of Lviv National University of veterinary medicine and biotechnologies named after S. Z. Gzhytskyj. Series "Ekonomical sciences", vol. 16, no. 3(60), part 5, pp. 125-139.

17. Levek, R. (2020), Agricultural structures, sustainability of food systems and land markets regulation. Ekonomika APK, vol. 1, pp. 18-33. https://doi.org/10.32317/2221-1055.202001018.

18. Zaburanna, L. and Yarmolenko, Yu. (2017), The social and economic preconditions of Ukrainian agricultural production development. Ekonomika APK, vol. 12, pp. 64-68.

19. Pidgrebelnaya, M. (2013), Agroholdings as the bigmarket oriented enterprises in agribusiness. Bulletin of Lviv National Agrarian University. Series: Economics of AIC, vol. 20(1), pp. 101-108.

20. Ozhelevska, T. (2011), The place of the cooperative movement in the socioeconomic development of rural areas. Scientific Journal of NULES of Ukraine. Series: Economy, Agrarian Management, Business, vol. 163, pp. 67-72.

21. Khalep, Yu. and Moskalenko, A. (2020), Ecological and economic aspects of the efficiency of Polissia organic plant models. Agricultural and Resource Economics, vol. 6, no. 4, pp. 5-19. https://doi.org/10.51599/are.2020.06.04.01.

22. Zinchuk, T. and Levkivskyi, Ye. (2019), Corporate social responsibility of vertically integrated entities as a condition of sustainable development. Ekonomika APK, vol. 1, pp. 39-49. https://doi.org/10.32317/2221-1055.201901039.

23. Borodina, O. M., Prokopa, I. V. and Popova, O. L. eds (2015), Polityka silskoho rozvytku na bazi hromad v Ukraini [Rural development policy based on communities], eds O. M. Borodina, I. V. Prokopa, O. L. Popova. NAS of Ukraine; Institute for Economics and Forecasting of NASU, Kyiv, Ukraine.

24. Dankevych, A. Y. (2011), Rozvytok intehrovanykh struktur u silskomu hospodarstvi [Development of integrated structures in agriculture], IAE, Kyiv, Ukraine.

25. Levkivska, L. and Levkovych, L. (2017), Social responsibility in Ukrainian agriculture: the regional issue. Eastern Journal of European Studies, vol. 8, is. 1, pp. 97-114.

26. Mints, A., Schumann, A. and Kamyshnykova, E. (2020), Stakeholders' rank of reflexion diagnostics in a corporate social responsibility system. Economic Annals$X X I$, vol. 181, is. 1-2, pp. 92-104. https://doi.org/10.21003/ea.V181-08. 
27. Pasko, O., Marenych, T., Diachenko, O., Levytska, I. and Balla, I. (2021), Stakeholder engagement in sustainability reporting: the case study of Ukrainian public agricultural companies. Agricultural and Resource Economics, vol. 7, no. 1, pp. 58-80. https://doi.org/10.51599/are.2021.07.01.04.

28. Irtyshcheva, I. and Stroyko, T. (2013), The conceptual foundations of the social infrastructure revival in the agri-food sector on the basis of sustainable development. Ekonomika pryrodokorystuvannia i okhorony dovkillia, no number, pp. $22-27$.

29. Galetska, T., Topishko, N. and Topishko, I. (2020), Social responsibility of economic enterprises as a social good: practice of the EU and Ukraine. Baltic Journal of Economic Studies, vol. 6, no. 3, pp. 24-35. https://doi.org/10.30525/22560742/2020-6-3-24-35.

30. Official web-site of SMIDA (2020), available at: https://smida.gov.ua/db/emitent/search.

31. Carroll, A. (1991), The pyramid of corporatesocial responsibility: toward the moral management of organizational stakeholders. Business Horizons, vol. 34, no. 4, pp. 39-48.

\section{Citation:}

Стиль - ДСТУ:

Skydan O., Budnik O., Sus L. The role of agroholdings in the creation of cooperatives by rural communities. Agricultural and Resource Economics. 2021. Vol. 7. No. 3. Pp. 107-122. https://doi.org/10.51599/are.2021.07.03.07.

Style-APA:

Skydan, O., Budnik, O. and Sus, L. (2021), The role of agroholdings in the creation of cooperatives by rural communities. Agricultural and Resource Economics, vol. 7, no. 3, pp. 107-122. https://doi.org/10.51599/are.2021.07.03.07. 